JURNAL ILMIAH KOMPUTER GRAFIS, Vol.14, No.1, Juli 2021, pp. 58 - 67

p-ISSN : 1979-0414(print)

e-ISSN : 2621-6256 (online)

http://journal.stekom.ac.id/index.php/pixel

\title{
Identitas Foto Wajah sebagai Keindahan dan Keburukan di Toko
}

\section{Online}

Sarwo Nugroho

Program Studi Desain Grafis, Universitas Sains dan Teknologi Komputer

Jl. Majapahit No. 605, Pedurungan Kidul, Kec. Pedurungan, Kota Semarang, Indonesia 50192

\section{ARTICLE INFO}

Article history:

Received 30 Mei 2021

Received in revised form 2 Juni 2021

Accepted 10 Juni 2020

Available online july 2020

\section{ABSTRACT}

Mengingat pandangan positif orang secara umum, penjual online mengalami kekhawatiran terhadap foto profil. Meskipun dari berbagai sumber adanya terihal tentang "kecantikan" dan "keburukan," penelitian ini tentang foto profil penjual pada toko online dari pelanggan ke pelanggan menemukan hubungan berbentuk kurva yang yang berhubungan antara daya tarik wajah yang efektif dan penjualan produk. Analisis dua data besar, penulis menemukan bahwa orang yang menarik dan tidak menarik menjual jauh lebih banyak daripada orang yang tampak biasa saja. Dua online eksperimen mengungkapkan bahwa penjual yang menarik menikmati kredibilitas sumber yang lebih besar karena kemampuan bersosialisasi dan kompetensi yang dirasakan, sedangkan penjual yang tidak menarik dianggap lebih dapat dipercaya berdasarkan kompetensi yang mereka rasakan. Sementara kecantikan adalah jelas untuk produk yang relevan dengan penampilan, keburukan lebih menonjol untuk produk yang relevan dengan keahlian dan untuk konsumen wanita mengevaluasi penjual pria. Temuan ini menyoroti pengaruh penampilan wajah sebagai sebagai identitas untuk kesan formasi dalam toko online dan efek kompleksnya dalam toko online dan pemasaran.

Kata kunci - daya tarik, kecantikan, toko online, penjualan, kecabtikan, keburukan 


\section{Pendahuluan}

Peran daya tarik dalam penilaian sosial dan keindahan telah didokumentasikan dengan baik di berbagai lingkungan sosial seperti kencan, perekrutan, penjualan, dan periklanan, terutama ketika tugas atau produk terkait dengan penampilan (Argo, Dahl, and Morales 2008; Eagly dkk. 1991; Langlois dkk. 2000). Beberapa penelitian telah menemukan hasil yang berlawanan ketika suatu produk tidak sesuai dengan penampilan, tetapi mereka belum memberikan penjelasan yang pasti untuk temuan ini (Kamins 1990; Trampe et al. 2010). Selain itu, sebagian besar peneliti membandingkan daya tarik terhadap model atau endorser dengan orang lain, sebagian besar mengabaikan orang-orang yang sama sekali tidak menarik. Penelitian terkini menunjukkan potensi keburukan : orang yang tidak menarik adalah dianggap lebih cerdas dan berpenghasilan jauh lebih banyak daripada rekan-rekan mereka yang menarik (misalnya, Gheorghiu, Callan, dan Sky2017; Kanazawa dan Still 2018), yang menunjukkan bahwa efek daya tarik adalah nonlinier. Dengan demikian, peneliti belum untuk mengidentifikasi mekanisme dan konteks mendasar yang tepat untuk kecantikan atau keburukan.

Pemasaran konvensional yang mengandalkan selebriti atau wiraniaga yang mempromosikan produk tertentu, tetapi pelanggan ke toko online melibatkan sebagian orang orang biasa atau tidak sebagai endorse dan ini nampaknya membuat masalah dari kredibilitas, membuat kredibilitas penjual masalah kritis (Luca 2017). Saat penjual online menunjukkan berbagai daya tarik, foto profil sebagai bagian integral dari identitas penjual dan berfungsi sebagai daya tarik utama untuk pembentukan kesan dan membangkitkan perasaan yang mempengaruhi pembeli (Forman, Ghose, dan Wiesenfeld 2008). Kebanyakan orang bagaimanapun, tidak diberkahi dengan simetri wajah yang sempurna dan proporsi. Mengingat meningkatnya popularitas sosial penjualan, bagaimana daya tarik seseorang atau kekurangannya mempengaruhi penjualan berbagai produk menjadi perhatian banyak kalangan online penjual dan sangat menarik bagi peneliti pemasaran dan praktisi.

Dalam menggambarkan pembentukan pesan, kecocokan dan evolusioner sebagai keputusan oleh penjual toko online yang menarik dan tidak menarik untuk mendapatkan perhatian dan kredibilitas daripada penjual yang biasa telah menghasilkan efek daya tarik berbetuk kurva U pada penjualan. Sementara wajah yang menarik tetap ada lebih baik dalam bersosialisasi daripada terlihat biasa dan tidak menarik orang, karena tidak dianggap lebih kompeten daripada tidak menarik. Orang - orang yang dianggap lebih kompeten daripada orang biasa orang yang terlihat polos. Perumusuan masalah dalam penelitian ini adalah, bagaimana kerangka kerja konseptual untuk efek daya tarik wajah sebagaimana keputusan pada konsumen ?. Sebagai tujuan penelitian ini untuk mengekstrak fitur geometris dari gambar wajah dan melakukan dengan observasi pada potret sebagai photo profil pada penjualan online. Selanjutnya melakukan penelitian tentang kecantikan dan keburukan melalui pendekatan multimetode melibatkan data data yang terkait dengan toko online dan pemasaran online.

\section{DESKRIPSI TEORITIS}

\section{A. Kesan dan Persepsi Wajah}

Wajah diketahui bias keputusan (Wheeler dan Petty 2001). Bentuk kesan pertama orang lain dan membuat penilaian tentang ciri-ciri sosial hampir seketika berdasarkan persepsi wajah (Samper, Yang, dan Daniels 2018; Todorov et al. 2005; Willis dan Todorov 2006). Mekanisme saraf di bawah tayangan sifat berbohong dari wajah melibatkan persspti, sub wilayah otak kortikal penting dalam pengkodean dari nilai rangsangan (Engell, Haxby, dan Todorov 2007). Dalam pemaknan persepsi telah diamati lebih sensitif terhadap yang tidak biasa daripada rangsangan yang netral, menunjukkan bahwa respons kita terhadap keduanya menarik dan wajah yang tidak menarik mungkin lebih kuat daripada yang terlihat biasa saja (Said, Baron, dan Todorov 2008).

Daya tarik wajah memicu kesimpulan otomatis yang cepat tentang disposisi orang yang pada gilirannya mempengaruhi pemrosesan informasi selanjutnya dan keputusan (Engell, Haxby, dan Todorov 2007). Perhatian yang lebih besar pada wajah yang menarik membuat lebih mungkin orang-orang memproses informasi tambahan yang terkait dengan wajah, yang dapat melemahkan tetapi tidak mengubah sifat hubungan antara kesimpulan dari wajah dan keputusan (Todorov et al. 2005; Vuil- leumier 2000). Dengan demikian, pengiklan merasa efektif untuk menggunakan keduanya model menarik atau tidak menarik untuk menyajikan produk tertentu (Guihair 2018). 


\section{B. Kecantikan dan Keburukan}

Pendapat psikologi evolusioner (Magro 1999), wajah yang menarik menunjukkan kesehatan dan kemakmuran yang baik. Kecantikan juga berkorelasi dengan kecerdasan yang dirasakan dan keterampilan sosial (Eagly et al. 1991; Hamermesh 2011). Pengacara yang menarik dapat memperoleh dua kali lipat banyak dalam sumbangan sebagai rekan-rekan mereka yang tidak menarik (Reingen dan Kernan 1993), dan wiraniaga yang tampan meningkatkan evaluasi pelanggan terhadap suatu produk hanya dengan menyentuhnya (Argo, Dahl, dan Morales 2008). Meskipun daya tarik dihargai dalam baik pria maupun wanita, pria lebih responsif terhadap fisik daya tarik wanita ( $\mathrm{Li}$ dan Kenrick 2006). Sementara itu, penelitian telah menemukan bahwa daya tarik terkadang gagal, misalnya, ketika membantu anak-anak yang membutuhkan atau menjual produk rassing (Fisher dan Ma 2014; Wan dan Wyer 2015).

Beberapa penelitian terbaru menunjukkan bahwa wajah yang tidak menarik dikaitkan dengan dengan hasil positif tertentu. Gheorghiu, Callan, dan Skylark (2017) menemukan bahwa siswa menilai profesor yang tidak menarik sebagai ilmuwan yang lebih baik daripada profesor yang menarik. Sebuah studi tentang pemenang Nobel memperkuat stereotip yang menyebar bahwa para ilmuwan mengorbankan daya tarik fisik untuk pengejaran intelektual (Fidrmuc, Paphawasit, dan Tunal; 2017). Kanazawa and Still (2018) di catat bahwa eksekutif yang sangat tidak menarik menghasilkan lebih banyak secara signifikan daripada rekanrekan mereka yang menarik, meskipun penelitian ini tidak mempertimbangkan persepsi kompetensi. Temuan ini mendukung kepercayaan populer bahwa orang yang tidak menarik mengerahkan upaya yang lebih besar untuk mengkompensasi penampilan mereka yang kurang beruntung; namun, studi ini gagal menawarkan penjelasan yang masuk akal untuk premi keburukan.

\section{A. Gambar Profile Online}

Forum online dan media sosial telah memperburuk koncern dengan penampilan dan sangat mempengaruhi sosial dan konsumen perilaku tion (Grabe, Ward, dan Hyde 2008). Keuntungannya anonimitas dan kurangnya sensor sosial langsung dapat membuat bias seperti itu lebih umum secara online (Guan et al. 2015). Platform transaksi online (misalnya, Uber, Airbnb) biasanya mengharuskan penjual untuk mengunggah foto asli sebagai foto profil mereka dan untuk menampilkannya di posisi yang menonjol. Foto profil ini tures memberikan informasi yang membawa kesan yang mempengaruhi kredibilitas sumber dan hasil perilaku (Forman, Ghose, dan Wiesenfeld 2008; Luka 2017).

Studi tentang efek daya tarik sebagian besar menggunakan gambar dalam pengaturan eksperimental daripada menilai menyanyikan situasi dunia nyata, meninggalkan kekokohan dan general kelayakan temuan mereka terbuka untuk dipertanyakan (Langlois et al. 2000). Tidak jelas dari literatur apakah sejenis berdasarkan daya tarik meluas ke konteks toko online. Peneliti mengadopsi model linier atau membandingkan hanya dua tingkat daya tarik (yaitu, menarik vs. kurang menarik), mengabaikan potensi efek nonlinier. Jadi, toko online yang melibatkan orang biasa menyediakan pengaturan yang sangat baik untuk mengeksplorasi efek keindahan dan keburukan serta mekanisme yang mendasarinya..

\section{Metode Penelitian}

Untuk mengeksplorasi potensi efek nonlinier dari daya tarik wajah pada penjualan produk, fokus pada gambar profil biasa orang-orang di toko online yang menampilkan berbagai daya tarik, yaitu menarik, tampak polos, dan tidak menarik. Untuk mekanisme penelitian yang mendasari keindahan dan keburukan, dilakukan eksperimen online untuk menilai efeknya daya tarik penjual pada persepsi keramahan dan potensi, yang pada gilirannya mempengaruhi kredibilitas dan pembelian oleh konsumen. Dengan tujuan ini dalam pikiran penilitian menyajikan -kerangka kerja konseptual pada Gambar 1 dan menguraikan hipotesis dalam bagian-bagian berikutnya.

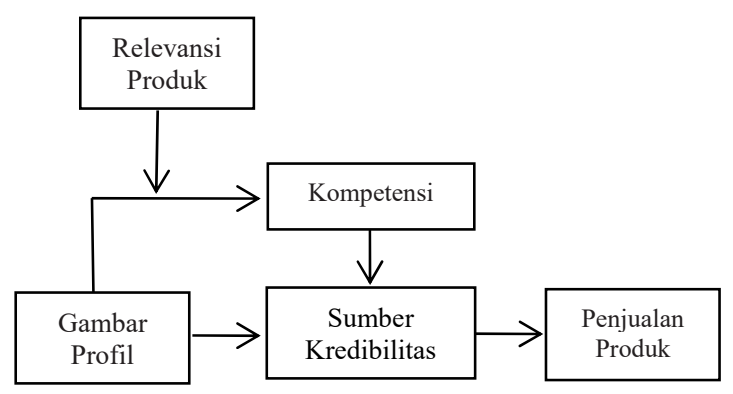


Gambar 1. Kerangka Konseptual Penelitian

\section{A. Mekanisme Premi Kecantikan dan Keburukan}

Wajah memiliki keunggulan khusus dibandingkan rangsangan lain dalam hal pemrosesan visual dan mekanisme pemusatan perhatian (Vuil-leumier 2000). Pada toko online yang melibatkan informasi kelebihan beban, wajah yang tidak biasa (menarik dan tidak menarik) memiliki nilai gairah yang tinggi dibandingkan dengan melihat wajah, dan dengan demikian pesan mereka lebih mungkin untuk lulus melalui gerbang perhatian daripada diabaikan. Baru penelitian menggunakan metode telah menemukan bahwa amigdala, bagian dari otak yang bertanggung jawab untuk perhatian dan pemrosesan visual, menunjukkan bit tanggapan nonlinier ke wajah manusia baik sebagai menarik dan wajah yang tidak menarik menimbulkan respons yang lebih cepat dan lebih kuat daripada yang tampak polos (Mart谋nLoeches et al. 2014; Said, Baron, dan Todorov 2008; Winston dkk. 2007).

Selain itu, orang secara instan menetapkan satu set ciri-ciri seperti kepribadian dan penilaian terhadap wajah, khususnya sepanjang dimensi kehangatan dan kompetensi (Fiske, Cuddy, dan Glick 2007). Penelitian menunjukkan bahwa baik- melihat orang dianggap lebih ramah, menyenangkan, cerdas lembut, dan persuasif (Hamermesh 2011). Orang yang tidak menarik dapat memperoleh penilaian positif yang berasal dari kesimpulan petence (Gheorghiu, Callan, dan Skylark 2017). Jadi, sementara premium kecantikan akan terlihat di platform online, kami juga berharap bahwa penjual yang tidak menarik menimbulkan persepsi positif dalam konteks tertentu, yang kami uraikan di bagian berikutnya. Kita mengusulkan bahwa dibandingkan dengan wajah yang tampak polos, keduanya menarik dan penjual yang tidak menarik menarik perhatian konsumen yang lebih dan inferensi sifat yang diinginkan, yang pada gilirannya mengarah pada kemungkinan penjualan.

$\mathrm{H}_{1}$ : Memegang hal-hal lain konstan, ada hubungan berbentuk U hubungan antara penjualan produk (atau niat beli) dan daya tarik wajah penjual online di keduanya menarik dan orang-orang yang tidak menarik tampil lebih baik daripada orang yang terlihat biasa saja orang-orang.

Namun, mendapatkan lebih banyak perhatian tidak bisa hanya membenarkan kelebihan wajah menarik dan tidak menarik dibandingkan wajah polos. Sejalan dengan teori kepribadian implisit, inferensi sifat adalah mekanisme kunci yang mendasari efek daya tarik (Eagly dkk. 1991). Selain pesan utama seperti produk, kualitas dan harga produk, kredibilitas sumber adalah faktor kunci yang mempengaruhi keputusan konsumen (Goldsmith, Lafferty, dan New- el 2000). Konsumen menggunakan isyarat nonverbal (wajah menarik) untuk menyimpulkan kepercayaan dan keahlian yang dirasakan dari sumber (yaitu, dua penentu kredibilitas sumber), yang dalam gilirannya mempengaruhi persepsi mereka tentang produk (Ohanian 1990).

Penelitian sebelumnya telah menyarankan bahwa daya tarik wiraniaga tiveness tidak secara langsung mempengaruhi kinerja penjualan tetapi, sebaliknya, mempengaruhi beberapa aspek kesan pelanggan terhadap tenaga penjual seperti sosialitas atau kompetensi (Ahearne, Gruen, dan Jarvis 1999; Debevec, Madden, dan Kernan 1986). Di platform online, fitur bergambar dan estetika profil gambar memiliki pengaruh besar pada penilaian konsumen. kredibilitas sumber (Carusi 2008). Sementara itu, atraksikeaktifan telah ditemukan berkorelasi sedang dengan sosialisasi yang dirasakan, kurang begitu dengan kompetensi, dan hampir sama sekali tidak jujur (Eagly et al. 1991; Grabe, Ward, and Hyde 2008). Dengan demikian, masuk akal bahwa keindahan dan keburukan premi beroperasi di bawah mekanisme yang berbeda dalam hal sosialisasi dan kompetensi.

Kecantikan, sebagai anugerah, memiliki banyak manfaat. Karena efek halo kecantikan, wajah yang menarik mengarah ke tingkat yang lebih tinggi gairah dan kesimpulan dari kemampuan bersosialisasi dan kompetensi (Langlois dkk. 2000). Bukti empiris yang kuat menunjukkan bahwa menarik individu dianggap memiliki lebih diinginkan secara sosial sifat dan menunjukkan kekuatan persuasif yang lebih besar dalam menjual produk dengan mana mereka terkait (Eagly et al. 1991; Ohanian 1990). Jadi, karena individu yang menarik dianggap sebagai lebih disukai dan kompeten, mereka dianggap lebih kredibel daripada yang terlihat biasa saja dan tidak menarik.

$\mathrm{H}_{2}$ : Dibandingkan dengan wajah yang tampak polos, wajah yang menarik meningkatkan (a) kemampuan bersosialisasi dan (b) kompetensi, yang pada gilirannya mempengaruhi (c) kredibilitas sumber dan (d) pembelian niat. 
Untuk wajah yang tidak menarik, perhatian saja mungkin tidak cukup untuk menimbulkan efek positif. Mengingat keindahan yang luar biasa premi untuk orang-orang yang menarik dan hukuman keburukan dalam pergaulan bility, orang yang tidak menarik memiliki keuntungan hanya atas orang biasa. melihat orang dalam kompetensi yang dirasakan karena beberapa alasan. Adaptasi kompensasi adalah persepsi yang dipegang secara luas bahwa tidak Orang-orang yang menarik sering kali bekerja lebih keras untuk mengkompensasi gangguan mereka. penampilan yang diuntungkan, yang mengarah ke persepsi yang lebih besar kompetensi dibandingkan mereka yang berwajah polos (Kock 2003). Ada persepsi yang mendarah daging bahwa sementara orang yang menarik dapatkan semuanya dengan lebih mudah, terutama dalam pengaturan yang membutuhkan keterampilan sosial, orang yang tidak menarik harus mengerahkan lebih banyak upaya untuk mengkompensasi penampilan mereka yang kurang beruntung dan sering berpindah ke area yang tidak menuntut keterampilan sosial, seperti pengejaran ilmiah (Fidrmuc, Paphawasit, dan Tunal; 2017).

Selain itu, efek "Einstein jelek" menunjukkan bahwa ahli stereotip mungkin menjadi pencari kebenaran yang tidak memihak dengan keterbatasan daya tarik pribadinya (Crane dan Patterson 2012; Gheorghiu, Callan, dan Sylark 2017). Keyakinan stereotip yang menarik tiveness dan kecerdasan berhubungan negatif juga pra-valen, terutama bagi perempuan (Heilman et al. 2004). Ini argumen digunakan untuk menjelaskan stereotip "pirang bodoh", di wanita menarik mana yang lebih mengandalkan penampilan mereka untuk maju daripada kecerdasan (Ruffle dan Shtudiner 2015). Tidak mengherankan, banyak bukti anekdotal ada pada kreativitas yang dirasakan dan karakteristik luar biasa dari orang yang tidak menarik (Guihaire 2018; Kaplan 1978). Penelitian kami memperluas gagasan ini dan mengusulkan bahwa premi keburukan beroperasi melalui persepsi kompetensi, yang pada gilirannya meningkatkan kredibilitas sumber dan niat beli.

$\mathrm{H}_{3}$ : Dibandingkan dengan wajah yang tampak polos, wajah yang tidak menarik meningkatkan (a) kompetensi yang dirasakan, yang pada gilirannya mempengaruhi (b) kredibilitas sumber dan (c) niat beli.

Relevansi produk didasarkan dengan baik dalam literatur yang ada pada daya tarik dalam pemasaran dan berfungsi sebagai moderator utama pada bagaimana daya tarik endorser atau tenaga penjual mempengaruhi kinerja mereka (Trampe et al. 2010). Menurut hipotesis kecocokan, pendukung berbagai tingkat daya tarik keaktifan lebih efektif ketika kemampuan yang mereka rasakan dan kredibilitas relevan untuk menyajikan dan menafsirkan produk produk (Kamins 1990). Mengikuti logika ini, kami berharap bahwa keuntungan dari wajah yang menarik dan tidak menarik lebih besar ketika mereka diselaraskan dengan produk yang relevan dengan sifat-sifat positif berasal dari penampilan mereka. Sedangkan orang yang menarik adalah lebih efektif dalam menghadirkan produk yang relevan dengan penampilan yang meningkatkan keramahan, wajah yang tidak menarik membawa keuntungan lebih wajah yang tampak polos ketika dikaitkan dengan suatu produk terkait dengan keahlian teknis atau profesional (misalnya, Bower dan Landreth 2001; Kang dan Herr 2006)

$\mathrm{H}_{4}$ : Relevansi produk memoderasi efek mediasi dari sosialisasi (kompetensi) antara kecantikan (kejelekan) pra-mium dan kredibilitas sumber. (a) Efek mediasi dari keramahan lebih kuat untuk orang yang menarik yang menjual produk yang relevan dengan penampilan, sedangkan (b) mediasi efek kompetensi lebih kuat untuk orang yang tidak menarik menjual ing produk keahlian yang relevan.

Selain itu, daya tarik mempengaruhi perbedaan pria dan wanita. dengan penuh semangat. Studi psikologi evolusioner menunjukkan bahwa pria lebih mementingkan daya tarik wanita, jadi pria konsumen lebih cenderung memberikan premium kecantikan untuk menarik penjual wanita tive (Agthe, Spörrle, dan Maner 2011). Bagaimana-pernah, meskipun wanita mungkin menghargai daya tarik pria, mereka lebih cenderung memprioritaskan pertimbangan dan tempat lain penekanan yang lebih besar pada kompetensi dan mendukung status dan kecerdasan gence pada pria karena kualitas ini menunjukkan kemampuan untuk memperoleh sumber daya dan memberikan keamanan (Sprecher, Sullivan, dan Hatfield 1994). Dengan demikian, premi keburukan dalam kompetensi adalah cenderung lebih kuat untuk konsumen wanita yang melihat pria Penjual.

$\mathrm{H}_{5}$ : Dibandingkan dengan setting sesama jenis, (a) mediasi efek sosialisasi untuk penjual wanita yang menarik lebih kuat untuk pembeli laki-laki dan (b) efek mediasi kompetensi untuk penjual pria yang tidak menarik lebih kuat untuk pembeli wanita. 


\section{Hasil dan Pembahasan}

Menentukan daya tarik wajah foto profil di Airbnb dan 5 miles adalah tugas yang menantang, seperti yang dimiliki situs-situs ini lebih dari 1 juta host dan 100.000 penjual, masing-masing. Karena standar daya tarik wajah bersifat universal lintas budaya, kelompok etnis, orientasi seksual, dan usia, daya tarik wajah, ness adalah sifat kuantitatif yang dapat dinilai oleh kedua orang dan algoritma komputer (Langlois et al. 2000; Magro 1999). Penerapkan metode pembelajaran mesin untuk memproses sejumlah besar banyak gambar profil dengan tingkat akurasi yang tinggi, membuat pengkodean manusia rumit dari semua potret yang tidak perlu.

Pertama, dengan mengambil sampel acak dari 32.386 foto profil dan merekrut sepuluh penilai pria dan sepuluh wanita antara 19 dan 25 tahun. Setiap gambar secara acak ditugaskan ke lima penilai (dua pria dan tiga wanita atau tiga pria) dan pria wanita), yang mencetaknya pada skala lima poin dari 1 ("sangat tidak menarik") hingga 5 ("sangat menarik"). Atraksi terakhir- skor tiveness adalah rata-rata dari lima peringkat. Secara acak membagi penilai menjadi dua kelompok dan diperoleh secara konsisten korelasi 0,87 hingga 0,96 untuk peringkat rata-rata antara kelompok. Statistik tidak signifikan menegaskan bahwa penilai menggunakan kriteria yang sama untuk menilai daya tarik wajah. Sebuah chi-uji kuadrat pada distribusi peringkat antara pria dan penilai perempuan juga mengungkapkan tidak ada perbedaan yang signifikan

Kedua, menggunakan teknik pemrosesan gambar untuk mengambil fitur bergambar utama. Bukti substansial dari komputasi dan penelitian estetika menunjukkan bahwa simetri dan proporsional fitur wajah nasional (misalnya, jarak antara mata, pipi lebar, ukuran hidung dan dahi) adalah prediktor yang baik dari wajah daya tarik (Gunes dan Piccardi 2006). Menggunakan satu set 68 landmark wajah untuk mengekstrak fitur ini dan menghitung berbagai compute rasio dan proporsi wajah. Misalnya, nilai estetika dard of golden ratio dapat diperoleh dengan membandingkan jarak antara mata dan mulut dengan jarak antara mulut dan dagu

Ketiga, menerapkan beberapa metode pembelajaran mesin (linier regresi, regresi Bayesian ridge, regresi Gaussian, mendukung regresi mesin vektor, regresi hutan acak, dan jaringan saraf convolutional) untuk mempelajari hubungannya antara geometri wajah dan skor daya tarik dari penilai manusia. Menggunakan $80 \%$ dari data potret sebagai set pelatihan untuk pemasangan model dan $20 \%$ sisanya untuk validasi pemilihan dan pemilihan model. Regresi hutan acak tercapai kinerja terbaik dalam hal korelasi Pearson, the berarti kesalahan absolut, serta biaya komputasi. Sehingga menerapkan regresi hutan acak untuk memprediksi wajah daya tarik semua gambar profil di kumpulan data 5miles sebagai berikut:

$$
\overline{r_{n}}\left(X, D_{n}\right)=E_{\Theta}\left[r_{n}\left(X, \Theta_{m}, D_{n}\right)\right]
$$

Di mana $\mathrm{r}$ ( $(\mathrm{X}, \mathrm{Y} \mathrm{m}, \mathrm{D} \mathrm{n})$ mengacu pada regresi dasar acak pohon. Y 1, Y $2, \ldots, \mathrm{Y}$ m terdistribusi secara identik dan independen keluaran dari variabel acak. E Y menunjukkan harapan sehubungan dengan parameter acak, kondisional pada kumpulan data D n dan X. Skor yang diprediksi sangat tinggi berkorelasi dengan orang-orang dari penilai ( $\mathrm{r}$.71). Selain itu validasi silang menggunakan set data pelatihan, mengadopsi dua lainnya prosedur 1 untuk menilai keakuratan pembelajaran mesin. Itu tes validasi menunjukkan bahwa algoritme berfungsi dengan baik untuk wajah dari berbagai jenis kelamin, usia, dan etnis, dan bahwa hasilnya dari penilai manusia sangat konsisten dengan orang-orang dari ran- regresi hutan dom.

Pengumpulan data pada semua data yang tersedia untuk umum untuk Daftar Airbnb di Los Angeles hingga 15 Juni 2017. Kemudian menambahkan data hunian tahunan dari pemasok data pada daftar Airbnb di seluruh dunia) yang mencakup: periode yang sama. Menggabungkan data dari sumber-sumber ini dan properti yang dikecualikan tanpa informasi lengkap (mis yang kurang dari satu tahun beroperasi). Kami mengunduh host gambar profil dan menggunakan teknik pemrosesan gambar untuk mengekstrak fitur bergambar. Sampel akhir terdiri dari 17.935 properti Airbnb dari 10.979 tuan rumah. Dari daftar tersebut, 17.749 memiliki gambar profil dan 9.953 menggunakan potret tunggal. Mengontrol untuk (1) karakteristik host (misalnya, verifikasi identitas kation, reputasi), (2) karakteristik daftar (misalnya, akomodasi jenis tanggal, harga, kode pos, usia listing, kualitas daftar foto), dan (3) karakteristik ulasan (misalnya, jumlah ulasan, peringkat properti oleh pengulas, sentimen ulasan). Ketiga kelompok variabel ini sangat penting untuk mengesampingkan potensi mengacaukan. Misalnya, kode pos sering digunakan untuk kontrol untuk perbedaan sosial ekonomi seperti kualitas perumahan di seluruh wilayah geografis, yang dapat mempengaruhi hasil yang bervariasi. sanggup. Hal ini juga berlaku untuk volume ulasan dan sentimen. Itu 
variabel terikatnya adalah tingkat hunian tahunan, yaitu a proxy untuk kinerja penjualan. Tabel 1 menyediakan variabel definisi dan ringkasan statistik

Spesifikasi model. Kami menggunakan kerangka kerja hierarkis untuk menilai pengaruh daya tarik tuan rumah terhadap tingkat hunian. Kira-sekitar 24\% tuan rumah memiliki lebih dari satu tempat, dan dengan demikian unit pengamatan adalah daftar. Kami memperkirakan model dalam mode bertahap. Model ekonometrika dasar adalah sebagai berikut :

$$
\begin{aligned}
\text { Occupancy }_{\mathrm{hl}}= & \beta_{0}+\beta_{1}(\text { pictorial features })+\mathrm{X}_{\mathrm{hl}} \beta_{2} \\
& +\mathrm{Y}_{\mathrm{h}} \beta_{3}+\mathrm{u}_{\mathrm{h}}+\mathrm{e}_{\mathrm{hl}},
\end{aligned}
$$

Pengumpulan data. Untuk memvalidasi temuan Studi 1a, kami menguji model menggunakan data dari 5miles. Melacak daftar produk setiap hari selama 60 hari (31 Januari hingga 31 Maret 2021) dalam tiga kategori produk_produk kecantikanucts (11.842 item), elektronik (7.171 item), dan tas (7.215 item) menghasilkan sampel 26.228 item dari 11.115 penjual. Sekitar $46 \%$ dari produk menerima setidaknya satu penawaran selama periode observasi. Kami menggunakan hal yang sama metode seperti dalam Studi 1a untuk mengekstrak fitur wajah dari penjual.

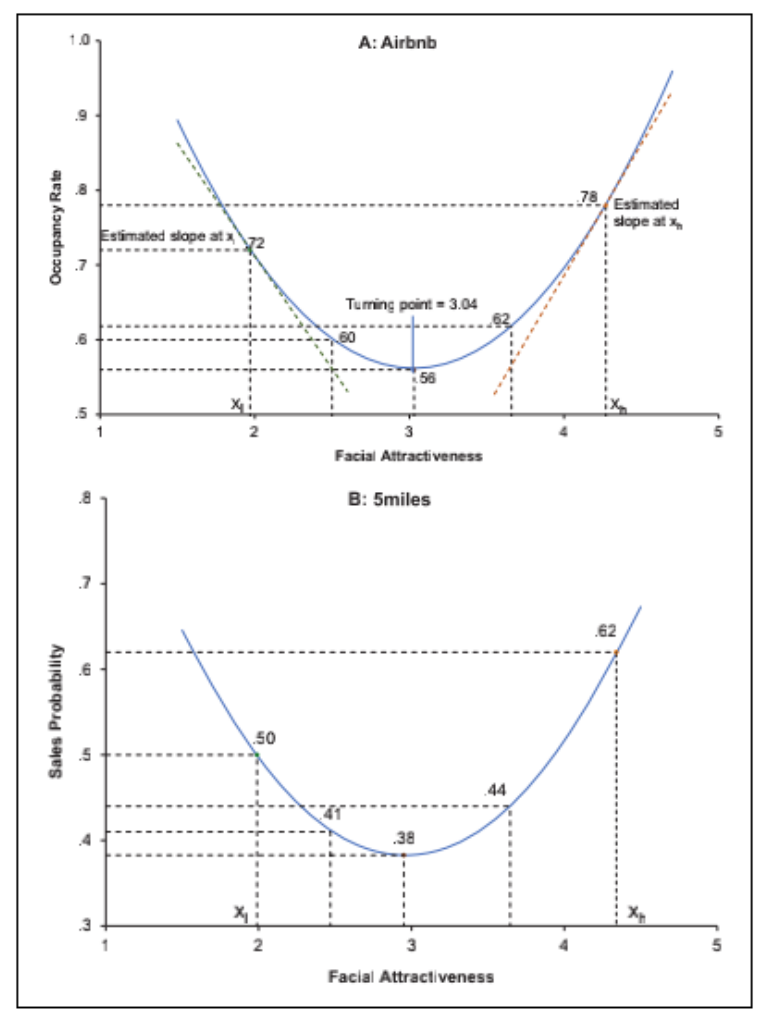

Gambar 2. Hubungan antara Daya Tarik Wajah dan Kinerja Penjualan

Dengan memilih foto penjual dari Chicago Face Database, yang memberikan resolusi tinggi, foto standar dari wajah laki-laki dan perempuan. Data norma yang luas tersedia untuk setiap foto individu termasuk atribut fisik juga sebagai penilaian subjektif oleh hakim independen (misalnya, menarik- ness, dapat dipercaya, feminin/maskulin). Manipulasi dari daya tarik, sementara sukses, dapat mempengaruhi persepsi dari kepercayaan penjual. Mengikuti penelitian sebelumnya (Kamin 1990; Till and Busler 2000), kami menghindari masalah ini dengan memilih penjual yang daya tariknya bervariasi namun setara kepercayaan yang luar biasa. Untuk mengontrol ekspresi wajah dan jenis kelamin, kami memilih tiga foto pria dan tiga foto wanita dengan wajah yang menarik, tampak polos, dan tidak menarik, semuanya netral ekspresi. Kecuali untuk foto, skenario untuk toko- tugas ping identik di seluruh kondisi 


\section{KESIMPULAN}

Tidak seperti penelitian sebelumnya tentang daya tarik yang berfokus pada sosial pilihan dalam pengaturan eksperimental, studi lapangan memeriksa pengaruh daya tarik wajah di antara sejumlah besar penjual pembeli dan pembeli dalam konteks e-niaga, di mana profi gambar berfungsi sebagai kendaraan utama untuk pembentukan kesan dan inferensi sifat. Meskipun literatur telah mendokumentasikan premium kecantikan dalam berbagai pengaturan dan kadang-kadang ditemukan premium keburukan, analisis terhadap puluhan ribu penjual gambar profil dari dua situs web memberikan bukti konvergen densitas hubungan berbentuk kurva $U$ antara daya tarik wajah dan penjualan. Adapun mekanisme yang mendasarinya, eksperimen hasil mendukung temuan sebelumnya tentang premium kecantikan dan hukuman keburukan ketika mengevaluasi keramahan penjual. Menemukan premi keburukan dalam kompetensi yang dirasakan untuk tidak menarik penjual tive atas orang-orang yang tampak biasa. Jadi, padahal menarik wajah menandakan kemampuan bersosialisasi dan kompetensi, wajah yang tidak menarik menimbulkan peningkatan persepsi kompetensi atas penjual dengan polos with terlihat, bahkan sedikit lebih dari orang-orang yang menarik. Jadi, bertentangan dengan gagasan kutukan keburukan, temuan kami menunjukkan bahwa wajah yang tampak biasa terjebak di tengah tanpa keuntungan nyata apa pun, karena mereka dianggap kurang ramah daripada orang yang menarik dan kurang kompeten dibandingkan orang yang tidak menarik.

Dengan demikian, ketika konsumen melakukan pembelian online, wajah penjual melayani fungsi pembeda yang penting untuk menyandikan penjual karakter, terkadang dengan cara yang tidak terduga. Selain itu, efek daya tarik dan sifat yang disimpulkan dimediasi oleh kredibilitas sumber dan tunduk pada pengaruh pentingnya variabel kontekstual yaitu, relevansi produk vanance (untuk penampilan atau keahlian) dan gender. Hasil kami mengungkapkan bahwa peran mediasi sosialisasi pada hubungan antara penjual yang menarik dan kredibilitas sumber secara signifikan lebih kuat untuk produk yang relevan dengan penampilan. Sebaliknya, efek mediasi kompetensi lebih terkait dengan produk produk yang keahliannya lebih penting daripada penampilan. Akhirnya, menemukan keburukan yang lebih besar untuk yang tidak menarik.

\section{UCAPAN TERIMA KASIH}

Terima kasih kepada pihak yang berperan dalam pelaksanaan kegiatan penelitian, laboratorium tempat penelitian yang telah berperan untuk mendukung penelitian ini.

\section{DAFTAR PUSTaka}

[1] Ahearne, Thomas W. Gruen, Michael, (1999), "If Looks Could Sell: Moderation and Mediation of the Attractiveness Effect on Salesperson Performance," International Journal of Research in Art, 18 (1), 268-84.

[2] Argo, Jennifer J., Darren W. Dahl, (2008), "Responses to Attractive Others in a Retail Context," Journal of Marketing Research, 45 (6), 695-701.

[3] Biddle, Jeff and Daniel Hamermesh (1995), "Beauty and the Market," American Economic Review, 84 (5), 174-94.

[4] Bower, Amanda B. and Stacy Landreth (2001), "Highly Versus Normally Attractive Models in Advertising," Jour nal of Advertising, 35 (1), 1-12.

[5] Carusi, Annamaria (2008), "Scientific Visualisations and Aesthetic Grounds for Trust," Information Technology and Ethics, 10 (4), 244-58.

[6] Chaiken, Shelly and Durairaj Maheswaran (1994), “Task Importance on Attitude Judgment and Heuristic Process ing Can Bias Systematic Processing: Effects of Source Credibility, Argument Ambiguity," Journal of Personality and Social Psychology, 66 (3), 465-73.

[7] Debevec, Kathleen, Thomas J. Madden, and Jerome B. Kernan (1986), "Message Evaluation, and Compliance: A Structural Examination,” Psychological Reports, 57 (2), 533-08.

[8] Eagly, Alice H., Richard D. Ashmore, Mona G. Makhijani, and Laura C. Longo (1991), "A Meta Analytic Review of Research on the Physical Attractiveness Stereotype," Psychological Bulletin, 111 (1), 109-28.

[9] Engell, Andrew D., James V. Haxby, and Alexander Todorov (2007), “ Automatic Coding of Face Properties in Human Amygdala," Journal of Cognitive Neu roscience, 13 (9), 1508-19.

[10] Ert, Eyal, Aliza Fleischer, and Nathan Magen (2016), "The Role of Personal Photos in Airbnb", Tourism Management, 55, 62-73. 
[11] Fidrmuc, Jan, Boontarika Paphawasit, and C, ig dem Bo“rke Tunalı (2017), "Nobel,” Working Paper, Rimini Center for Eco nomic Analysis.

[12] Fisher, Robert J. and Yu Ma (2014), "Negative Effects of Attractiveness on Empathy for Children in Need," Journal of Consumer Research, 41 (2), 436-50.

[13] Fiske, Susan T., Amy J.C. Cuddy, and Peter Glick (2007), "Warmth and Competence," Trends in Cognitive Science, 11 (2), 77-83.

[14] Forman, Chris, Anindya Ghose, and Batia Wiesenfeld (2008), "The Role of Reviewer Identity Disclosure in Electronic Markets," Information Systems Research, 19 (3), 291-313.

[15] Gheorghiu, Ana I., Mitchell J. Callan, and William Skylark (2017), "Facial Appearance Affects Science Communication," Proceed ings of the National Academy of Sciences of the United States of America, 114 (23), 5970-75.

[16] Goldsmith, Ronald E., Barbara A. Lafferty, and Stephen J. Newell (2000), “The Impact of Corporate Credibility and Celebrity Credibility on onsumer Reaction to Advertisements and Brands," Journal of Advertising, 29 (3), 43-54.

[17] Grabe, Shelly, Monique L. Ward, and Janel S. Hyde (2008), "The Role of the Media in Body Image: A Meta Analysis of Experimental and Correlational Studies," Psychologi cal Bulletin, 134 (3), 460-76.

[18] Guan, Shu-Sha A., Kaveri S., Kevin Linares, and Roy Cheng (2015), “Attractiveness in a Virtual World," Cyberpsychology: Journal of Psychosocial Research on Cyberspace, 8 (2), 1-29.

[19] Guihaire, Edouard (2019), "an Agency of Extraordinary Character," The Jakarta Post (February 16), http://www.thejakartapost.com/life/2018/02/16/ugly-models-an-agency-of-extraordinarycharacters.html.

[20] Gunes, Hatice and Massimo Piccardi (2006), “Assessing Facial Through Proportion Analysis by Image Processing and Supervised Learning," International Journal of Human Computer Studies, 64 (12), 1184-99.

[21] Hamermesh, Daniel S. (2011), Why Attractive People Are More Successful. Princeton: Princeton University Press.

[22] Heilman, Madeline E., Aaron S. Wallen, Daniella Fuchs, and Melinda M. Tamkins (2004), "Reactions to Women Who Succeed at Male Gender-Typed Tasks," Journal of Applied Psychology, 89 (3), 41627.

[23] Kamins, Michael A. (1990), “An Investigation into the 'Match-Up':When Beauty May Be Only Skin Deep,” Journal of Advertising, 19 (1), 4-13.

[24] Kanazawa, Satoshi and Mary C. Still (2018), "Is There Really a Beauty Premium or an Ugliness Penalty on Earnings?" Journal of Business and Psychology, 33 (2), 234-62.

[25] Kang, Yong-Soon and Paul M. Herr (2006), "Toward an Integrative Model of Communication Source Effects," Journal of Consumer Research, 33 (6), 123-30.

[26] Kaplan, Robert M. (1978), "I Sex Interaction in the Attractiveness Halo Effect," Sex Roles, 4 (2), 195-204.

[27] Keh, Hean Tat, Run Ren, Sally Rao Hill, and Xuan Li (2013), “The Effects of Service Employee Attributes on Customer Satisfaction," Psychology and Marketing, 30 (3), 211-26.

[28] Kock, Ned (2003), Compensatory Adaptation: Understanding How Obstacles Can Lead to Success. Conshohocken, PA: Infinity Publishing.

[29] Kamins, Michael A. (1990), "Sebuah Investigasi ke 'Match-Hipotesis dalam Iklan Selebriti: Ketika Kecantikan Mungkin SajaSkin Deep," Jurnal Periklanan, 19 (1), 4-13.

[30] Kanazawa, Satoshi dan Mary C. Still (2018), "Benarkah Ada Premium Kecantikan atau Penalti Keburukan atas Penghasilan?” Jurnal Bisnis dan Psikologi, 33 (2), 249-62.

[31] Kang, Yong-Soon dan Paul M. Herr (2006), "Kecantikan dan Pemirsa: Menuju Model Komunikasi Integratif Sumber Efek," Jurnal Riset Konsumen, 33 (6), 123-30.

[32] Kaplan, Robert M. (1978), "Apakah Bakat Kecantikan? Interaksi Seks di Daya Tarik Halo Efek," Peran Seks, 4 (2), 195-204.

[33] Keh, Hean Tat, Run Ren, Sally Rao Hill, dan Xuan Li (2013), "The Cantik, Ceria, dan Bermanfaat: Efek Pelayanan Atribut Karyawan pada Kepuasan Pelanggan, "Psikologi dan Pemasaran, 30 (3), 21126.

[34] Kock, Ned (2003), Adaptasi Kompensasi: Memahami Bagaimana Hambatan Dapat Membawa Kesuksesan. Conshohocken, PA: Infinity Penerbitan

[35] Langlois, Judith H., Lisa Kalakanis, Adam J. Rubenstein, Andrea

[36] Larson, Monica Hallam, and Monica Smoot (2000), "Maxims or 
[37] Myths of Beauty? A Meta-Analytic and Theoretical Review," Psy chological Bulletin, 126 (3), 390423.

[38] Lee, Margaret, Marko Pitesa, Madan M. Pillutla, and Stefan Thau (2018), "Perceived Entitlement Causes Discrimination Against Attractive Job Candidates in the Domain of Relatively Less Desir able Jobs," Journal of Personality and Social Psychology, 114 (3), 422-42.

[39] Li, Norman P. and Douglas T. Kenrick (2006), "Sex Similarities and Differences in Preferences for Short-Term Mates: What, Whether, and Why," Journal of Personality and Social Psychology, 90 (3), 468-89.

[40] Mattes, Kyle, Michael Spezio, Hackjin Kim, Alexander Todorov, Ralph Adolphs, and R. Michael Alvarez (2010), "Predicting Election Outcomes from Positive and Negative Trait Assessments of Candidate Images," Political Psychology, 31 (1), 41-58.

[41] McColl, Rod and Yann Truong (2013), "The Effects of Facial Attractiveness and Gender on Customer Evaluations During a Web-Video Sales Encounter," Journal of Personal Selling \& Sales Management, 33 (1), 117-28.

[42] Ohanian, Roobina (1990), "Construction and Validation of a Scale to Measure Celebrity Endorsers' Perceived Expertise, Trustworthiness, and Attractiveness," Journal of Advertising, 19 (3), 39-52.

[43] Reingen, Peter H. and Jerome B. Kernan (1993), "Social Perceptionand Interpersonal Influence: Some Consequences of the Physical Attractiveness Stereotype in a Personal Selling Setting," Journal of Consumer Psychology, 2 (1), 25-38.

[44] Ruffle, Bradley J. and Ze'ev Shtudiner (2015), "Are Good-Looking People More Employable?" Management Science, 61 (8), 1760-76.

[45] Said, Christopher P., Sean G. Baron, and Alexander Todorov (2008), "Nonlinear Amygdala Response to Face Trustworthiness: Contri butions of High and Low Spatial Frequency Information," Journal of Cognitive Neuroscience, 21 (3), 519-28.

[46] Samper, Adriana, Linyun W. Yang, and Michelle E. Daniels (2018), "Beauty, Effort, and Misrepresentation: How Beauty Work Affects Judgments of Moral Character and Consumer Preference," Journal of Consumer Research, 45 (1), 126-47.Vuilleumier, Patrik (2000), "Faces Call for Attention: Evidence from

[47] Patients with Visual Extinction," Neuropsychologia, 38 (5), 693-700. Wan, Lisa C. and Robert S. Wyer (2015), "Consumer Reactions to Attractive Service Providers: Approach or Avoid?” Journal of Consumer Research, 42 (4), 578-95.

[48] Wang, Ze, Huifang Mao, Yexin Jessica Li, and Fan Liu (2017), "Smile Big or Not? Effects of Smile Intensity on Perceptions of Warmth and Competence," Journal of Consumer Research, 43 (5), 787805.

[49] Wheeler, S. Christian and Richard E. Petty (2001), "The Effects of Stereotype Activation on Behavior: A Review of Possible Mechan isms," Psychological Bulletin, 127 (6), 797-826.

[50] Willis, Janine and Alexander Todorov (2006), "First Impressions: Making Up Your Mind After a 100Ms Exposure to a Face," Psychological Science, 17 (7), 592-98.

[51] Winston, Joel S., John O’Doherty, James M. Kilner, David I. Perrett, and Raymond J. Dolan (2007), "Brain Systems for Assessing Facial Attractiveness," Neuropsychologia, 45 (1), 195-206.

Yang, Mochen, Gediminas Adomavicius, Gordon Burtch, and Yuqing Ren (2018), "Mind the Gap: Accounting for Measurement Error and Misclassification in Variables Generated Via Data Mining," Information Systems Research, 29 (1), 4-24. 